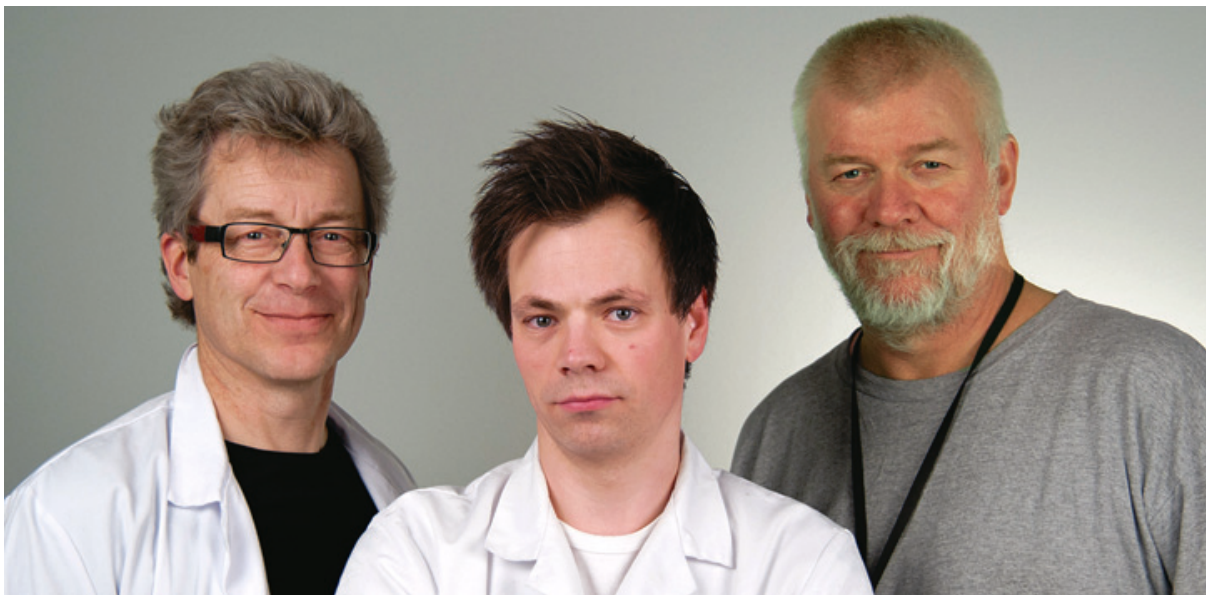

Tre av forfatterne: Ivar S. Nordrum, Joachim Frost og Lars Slørdal. Foto Jørn Ove Sæternes, Norges teknisknaturvitenskapelige universitet

\title{
Store forskjeller i obduksjonshyppighet
}

Andelen dødsfall der det blir foretatt rettslig obduksjon er svært ulik i nabofylkene Sør-Trøndelag og Nord-Trøndelag, til tross for felles lovregler.

Obduksjon kan gi vesentlig informasjon om dødsårsaker, især ved uklare og mistenkelige dødsfall. Obduksjonsfrekvensen har falt i mange land de siste tiårene. Norske forskere har nå kartlagt praksis ved begjæring av rettslig obduksjon i Midt-Norge (1).

I perioden 2007-09 ble det begjært 364 rettslige obduksjoner i Sør- og Nord-Trøndelag, dvs. ved $3 \%$ av alle dødsfall. Høyest obduksjonsrate var det ved antatt drap $(100 \%)$, selvmord (63\%), forgiftninger ( $84 \%)$ og veitrafikkulykker (57\%), lavest ved naturlige dødsfall ( $1 \%)$, fallulykker $(12 \%)$ og den heterogene gruppen «andre ulykker» $(21 \%)$. Obduksjonsraten falt med økende alder og var høyere for menn enn for kvinner ( $5 \%$ versus $2 \%$ ). Ratene var lavere i Nord-Trøndelag enn i Sør-Trøndelag - mest slående var forskjellen ved selvmord: $11 \%$ versus $91 \%$.

Forekomsten av alkohol, medikamenter og andre substanser ble også registrert. Dette er funn som med stor sannsynlighet ikke blir erkjent uten gjennomføring av obduksjon. De klart hyppigst påviste stoffklassene var benzodiazepiner, opioider og alkohol.

- Denne studien viser etter vår mening at det er for lave obduksjonsrater ved flere dødsmåter, bl.a. etter voldsomme dødsfall som veitrafikkulykker og andre ulykker. De store forskjellene i obduksjonsrate mellom de to fylkene, på tross av likt lovverk for begjæring av rettslig obduksjon, er også bemerkelsesverdig, sier førsteforfatter Joachim Frost ved Norges teknisk-naturvitenskapelige universitet og St. Olavs hospital.

- Vi mener at obduksjon er et viktig korrektiv til klinisk stilte diagnoser og dødsårsaker, og at adekvat obduksjonshyppighet er nødvendig for å sikre kvaliteten og vali- diteten til dødsårsaksstatistikken. Manglende obduksjon kan også ha strafferettslig betydning og ha noe å si for forsikringsoppgjør og informasjon til pårørende.

Studien er en av svært få systematiske undersøkelser av hyppigheten av rettslig obduksjon. Toksikologifunnene indikerer at alkohol, rusmidler og legemidler utgjør en vesentlig faktor ved plutselig, uventet død, og at en grundig og fullstendig toksikologisk analyse er påkrevd ved undersøkelse av slike dødsfall, sier Frost.

\section{Rettstoksikologiprosjektet (ForTox)}

Datamaterialet i studien stammer for en stor del fra Rettstoksikologiprosjektet (ForTox), et forskningsprosjekt som ble etablert av det rettspatologiske og farmakologiske fagmiljøet ved Norges teknisk-naturvitenskapelige universitet og St. Olavs hospital i 2006. Artikkelens førsteforfatter, Joachim Frost, ble tilknyttet prosjektet som stipendiat i 2010. Gjennom innsamling av kliniske opplysninger og kroppsvæske- og vevsprøver fra rettslige obduksjoner i Midt-Norge skal prosjektet bidra til bedre beslutningsgrunnlag innen rettsmedisinsk sakkyndighet. Både kliniske data og biologisk prøvemateriale registreres og lagres i Regional forskningsbiobank Midt-Norge. De toksikologiske analysene utføres ved Avdeling for klinisk farmakologi, St. Olavs hospital.

\section{Erlend Hem}

erlend.hem@medisin.uio.no

Tidsskriftet

\section{Litteratur}

1. Frost J, Slørdal L, Vege A et al. Forensic autopsies in a naturalistic setting in Norway: autopsy rates and toxicological findings. Forensic Sci Int 2012; 223: $353-8$
Ordforklaringer

Rettslig obduksjon: Ifølge påtaleinstruksen skal politiet påse at sakkyndig likundersøkelse foretas når det er mistanke om at døden er forårsaket av en straffbar handling. Politiet bør i alminnelighet sørge for slik undersøkelse når dødsårsaken er uviss og antas å kunne skyldes et ulykkestilfelle. Slik sakkyndig likundersøkelse er i praksis rettslig obduksjon. Ved rettslig obduksjon kartlegges og dokumenteres ytre og indre skader, ev. sykdommer og forekomst av alkoholer, medikamenter og andre substanser i kroppsvæsker.

Obduksjonsrate: Andelen obduserte av alle døde innenfor en gitt kategori, f.eks. en gitt dødsmåte som selvmord, veitrafikkulykke, forgiftning etc.

Toksikologisk analyse: Laboratorieanalyser om forekomst av alkoholer, medikamenter og andre substanser i kroppsvæsker og vev, fortrinnsvis blod og urin. Utføres rutinemessig ved rettslige obduksjoner, og omfatter da i regelen både screeningundersøkelser og spesifikke analyser.

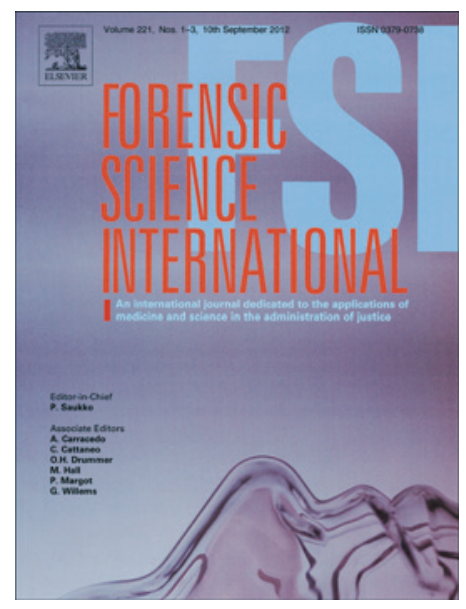

Artikkelen ble e-publisert 3.11. 2012 i Forensic Science International (www.fsijournal.org), som er et ledende rettsmedisinsk tidsskrift. 